\title{
PERBEDAAN INDIKATOR-INDIKATOR PENYEMBUHAN LUKA TIKUS WISTRAR NON DIABETIK DAN DIABETIK PADA PEMBERIAN CURCUMIN TOPIKAL
}

\author{
Tejo Jayadi, Arum Krismi \\ Fakultas Kedokteran Universitas Kristen Duta Wacana \\ Korespondensi: tejo_jayadi@staff.ukdw.ac.id
}

\begin{abstract}
ABSTRAK
Latar Belakang: Di dunia dan Indonesia, penderita diabetes melitus akan meningkat, diperkirakan dua kali. Hal ini menyebabkan peningkatan jumlah penderita ulkus diabetikum, pada akhirnya dapat menyebabkan amputasi. Banyak faktor pertumbuhan berperan dalam penyembuhan luka, diantaranya TGF beta1 dan p63. Pada luka kronik, ekspresi TGF beta 1 menurun, sementara peran utama p63 adalah pertumbuhan epidermis. Curcumin memperbaiki penyembuhan luka.

Tujuan Penelitian: Tujuan penelitian adalah untuk mengenali efek kurkumin pada penyembuhan luka tikus wistar non diabetic dan diabetic dengan menilai ekspresi TGF beta1 dan p63, tingkat inflamasi, jaringan granulasi, dan penutupan dermis.

Metode Penelitian: Penelitian dikerjakan dengan metode quasi eksperimental dengan desain post-test only control group design pada 64 hewan coba, dengan 16 tikus non diabetik diterapi curcumin (A), 16 hewan coba diabetik tanpa curcumin (B), 16 tikus diabetik tanpa curcumin (C), 16 tikus diabetik diterapi salep curcumin (D).

Hasil dan Diskusi: Pada uji marginal homogeneity derajat inflamasi sampel A terhadap sampel $B$ adalah $p=0,166$, level ekspresi TGF beta 1 nilai $p=0,03$, pembentukan jaringan granulasi $p=0,317$, penutupan dermis nilai $p 0,317(p=0,05)$, ekspresi p63 nilai p=0,005. Curcumin meningkatkan derajat inflamasi dan level ekspresi TGF beta1 yang cenderung mempercepat proses penyembuhan luka pada hewan coba non diabetes. Uji marginal homogeneity sampel C dan D menunjukkan inflamasi nilai $\mathrm{p}=0,197$, pembentukan jaringan granulasi $\mathrm{p}=0,564$, sedang penutupan dermis sampel $D p=0,083$, ekspresi TGF beta1 $p=0,884$, ekspresi $p 63$ $\mathrm{p}=0,025$. Curcumin meningkatkan ekspresi p63, tetapi tidak mempercepat proses penyembuhan luka.
\end{abstract}

Kata Kunci: curcumin, TGF beta-1, p63, level inflamasi, penutupan dermal, waktu penyembuhan luka 


\title{
THE DIFFERENCES OF WOUND HEALING INDICATORS IN NON DIABETIC AND DIABETIC WISTAR RAT IN TOPICAL APPLICATION OF CURCUMIN
}

\author{
Tejo Jayadi, Arum Krismi \\ Medical Faculty of Duta Wacana Christian University \\ Correspondence: tejo_jayadi@staff.ukdw.ac.id
}

\begin{abstract}
Background: The world and Indonesia, it will be an increased in number of patients with diabetes mellitus, estimated doubling. It brings an increasing in number of patients with diabetic ulcers, which in the end causing amputation. Many growth factors are playing a role in wound healing such as TGF beta-1 and p63. In chronic wound, the expression of TGF-beta 1 declines, while the essential role of $p 63$ is to grow the epidermis. Curcumin accelerates wound healing.

Research Purpose: The research aims is to recognize the effect of curcumin on wound healing in non diabetic and diabetic wistar rats by measuring TGF-beta 1 expression and p63 expression, level of inflammation, and the closure of dermal, wound healing time.

Research Methods: The research is carried out with the method of quasi experimental with post-test only control group design on 64 experimental animal with 16 non diabetic treatment with curcumin (A) and 16 nondiabetic rats treatment with placebo $(B)$ and 16 diabetic treatment with placebo $(C)$ and 16 diabetic rats treatment with curcumin ointment $(D)$.

Result and Discussion: In this research, the ethanol extract of curcuma longa fractionation with ethyl acetate did not show a statistically increased closing time of wound and closing time of dermal in non diabetic and diabetic wistar rat, although TGF beta 1 and p63 expression shows an increase in the granting of the ethanol extract of curcuma longa fractionation with ethyl acetate.
\end{abstract}

Keywords: curcumin, TGF beta-1, p63, the level of inflammation, the closure of dermal, wound healing time 


\section{PENDAHULUAN}

Prevalensi penderita DM pada orang dewasa di dunia menurut American Diabetes Ascociation (ADA) berkisar $8,7 \%$ pada tahun 2002 sebagian besar tergolong diabetes tipe 2. World Health Organization (WHO) memprediksi akan terjadi kenaikan jumlah pasien dari 8,4 juta pada tahun 2000 menjadi 21,3 juta pada tahun 2030. Diabetes Melitus di Indonesia diduga belum terdiagnosis sekitar $50 \%$. Prevalensi DM di Manado mencapai $6 \%$, di Kotamadya Surabaya 4,16 \%. Di Desa Sangsit Buleleng Bali prevalensi DM 7,5 \%. ${ }^{1}$ Penderita diabetes sering mengalami komplikasi ulserasi kaki, infeksi, neuropati perifer, yang sering menyebabkan amputasi pada ekstremitas yang terkena, sehingga cara penatalaksanaan dan perawatan luka baik dan benar adalah strategi pencegahan yang tepat. ${ }^{2}$

Diabetes melitus dapat menimbulkan ulserasi kronik, disebabkan karena rendahnya bioaviabilitasfaktor-faktor pertumbuhan dan reseptornya, produksi/modifikasi protein-protein matrik yang tidak normal, hilangnya kapasitas proliferasi sel-sel di dalam lokasi luka, dan gangguan perfusi. $^{3}$ Sel-sel punca epidermis berada pada daerah tonjolan folikel rambut, interfollicular epidermis, kelenjar sebasea dan didapatkan juga pada sel-sel mononuklear dalam darah perifer. Sel-sel punca keratinosit tersebut berproliferasi dan berdiferensiasi menjadi sel dewasa, dapat dideteksi dengan marker p63, di mana p63 juga merupakan faktor transkripsi. ${ }^{4,5}$ Ekspresi transforming growth factor-beta1 (TGF- $\beta 1$ ) tidak meningkat pada ulkus kaki diabetik dibandingkan dengan jaringan kulit penderita diabetik dan yang sehat. Kurangnya up-regulation TGF- $\beta 1$ pada ulkus kaki diabetes menjelaskan gangguan penyembuhan luka kronik ini. $^{6}$ TGF- $\beta 1$ adalah stimulator terpenting untuk sintesis kolagen dan proteoglikan serta mencegah kerusakan matrik ekstraseluler, mendorong migrasi keratinosit dan reepitelisasi pada luka partial thickness hewan coba tikus. ${ }^{7}$

Reepitelisasi diorkestrai oleh proliferasi dan migrasi keratinosit yang berkorelasi dengan ekspresi p63, suatu marker dari sel-sel tidak terdiferensiasi yang berproliferasi, dan pertumbuhan dari epitel bertingkat. ${ }^{8}$ Pada pasien dengan epidermis sehat, p63 menjaga potensial sel progenitor dengan menjaga kemampuannya untuk membelah, bertanggung jawab memproteksi fenotipe epitelial dari deplesi karena sel-selnya bermigrasi. ${ }^{9}$ Penurunan ekspresi p63 pada pasien dengan ulserasi venosa menyimpulkan insufisiensi protein untuk perawatan autoregenerasi dan pembelahan berkesinambungan, keduanya dibutuhkan untuk menunjang migrasi sel-sel tersebut. Disimpulkan adanya peranan p63 dalam regulasi proses penyembuhan dan patofisiologi dari ulserasi kronik vena tungkai. Pada penelitian dengan hewan coba tikus dengan perlakuan luka bakar dan diaplikasikan curcumin secara topikal didapatkan peningkatan ekspresi proliferating cell nuclear antigen di dalam jaringan kulit dari hewan coba yang diberi apilikasi curcumin. ${ }^{10}$

Masalah dalam penelitian ini ada dua yaitu mencari perbedaan ekspresi TGF- $\beta 1$, p63 dan waktu penyembuhan luka dinilai dari indikator faktor-faktor histopatologi yaitu penutupan luka, inflamasi dan penutupan dermis, yang diinduksi oleh curcumin dibandingkan dengan placebo, pada penyembuhan luka tikus wistar non diabetik dan diabetik dan mencari perbedaan ekspresi TGF- $\beta 1$, p63 dan waktu penyembuhan luka dinilai dengan indikator faktor- 
faktor histopatologi, pada proses penyembuhan luka tikus wistar non diabetik dibandingkan diabetik, yang diinduksi curcumin.

\section{METODOLOGI PENELITIAN}

Penelitian ini dikerjakan
dengan metode penelitian quasi
eksperimental dengan model posttest
only with control group design, di mana
pengujian dilakukan setelah perlakuan
dengan kelompok kontrol sebagai
pembandingnya.

Populasi pada penelitian ini adalah tikus wistar usia 12-16 bulan dengan berat 250-300 gram dari penangkaran LPPT IV UGM. Sampel penelitian diambil dari jaringan lokasi luka dan dibuat blok parafin untuk pemeriksaan histopatologi dan imunohistokimia di Instalasi Patologi Anatomi RS DR. Sardjito/Bagian Patologi Anatomi Fakultas Kedokteran Universitas Gadjah Mada.

Kriteria inklusi: Tikus wistar lakilaki, kondisi sehat (bergerak dengan aktif) berusia 12-16 bulan dengan berat 250-300 gram. Kriteria eksklusi: Tikus wistar laki-laki menunjukkan perubahan perilaku (aktivitasnya tampak lemah dan malas).

Pembuatan salep curcumin dilakukan di Fakultas Farmasi UGM dan LPPT 1 UGM. Curcumin diperoleh dengan cara mengekstrak metabolit sekunder dari kunyit (Curcuma longa) kemudian difraksinasi dengan etil asetat.

Sejumlah empat hewan coba tikus wistar jantan tanpa perlakuan baik non diabetik dan diabetik dikerjakan eksisi pada hari ke 30 dan dilanjutkan pemeriksaan histopatologi dan imunohistokimia. Lima belas hewan coba tikus wistar jantan dengan perlakuan non diabetik dilakukan insisi berdasarkan prosedur, kemudian diberikan salep curcumin satu hari sekali untuk sampel A dan placebo untuk sampel $\mathrm{B}$, dan dilakukan pengambilan tiga sampel sesuai prosedur setiap hari ke-1, 3, 12, 18 dan 30. ${ }^{11}$ Tiga puluh tikus wistar diabetik dikerjakan injeksi streptozotocin sesuai prosedur untuk menginduksi diabetes. Lima belas hewan coba tikus wistar jantan dengan perlakuan diabetik dilakukan insisi berdasarkan prosedur, kemudian diberikan placebo satu hari sekali untuk sampel C dan salep curcumin untuk sampel $\mathrm{D}$, dilakukan pengambilan tiga sampel sesuai prosedur setiap hari ke1, 3, 12, 18 dan 30. Sampel A, B, C, D dikerjakan pemeriksaan histopatologi dengan pewarnaan H\&E dan pengecatan imunohistokimia TGF-beta1 dan p63.

Kelompok diabetik diinjeksi dengan Streptozotocin $40 \mathrm{mg} / \mathrm{kgBB}$ dosis tunggal untuk menginduksi diabetes. Sepuluh hari setelah kadar glukosa darah mencapai dua kali dari level gula darah awal, tikus wistar digunakan sebagai hewan coba.

Insisi dilakukan dengan anestesi umum menggunakan ketalar $2 \mathrm{mg}$ intraperitoneal. Setelah hipoestesia tercapai, rambut pada regio tulang belakang di punggung paling atas dicukur, kemudian dilakukan insisi sepanjang $2 \mathrm{~cm}$ sampai seluruh ketebalan kulit (epidermis sampai hipodermis) terpisah. ${ }^{12,13}$ Luka dibiarkan terbuka, tidak ditutup dengan penutup apapun. ${ }^{14}$

Pengambilan jaringan luka dilakukan dengan mengorbankan hewan coba menggunakan eter. Setelah efek tercapai, dilakukan eksisi pada bagian luka yang paling luas dengan mengikutsertakan jaringan kulit normal, kemudian difiksasi dalam formalin buffer $10 \%$ untuk dilakukan pemeriksaan histopatologi dan imunohistokimia.

Penghitungan densitas ekspresi TGF beta 1 dengan cara semiquantitatif. 
Intensitas ekspresi diskor 4:0 bila tidak ada ekspresi pada sel; 1) bila pewarnaan lemah; 2) bila pewarnaan sedang; 3) bila pewarnaan kuat. Persentasi sel yang terwarnai diskor: 0 bila tidak ada ekspresi pada sel; 1 bila $<33 \%$ ekspresi pada sel; 2 bila 33-66\% ekspresi pada sel, 3 bila $>66 \%$ ekspreasi pada sel. Dihitung pada 100 sel pada daerah hot spot. Kemudian dijumlah bila skor 0-1: negatif, 2: positif lemah, 3-4: positif sedang, 5-6: positif kuat. ${ }^{15}$ Ekspresi TGF beta 1 diekspresikan pada fibroblast, neutrofil, limfosit, sel plasma dan makrofag. ${ }^{16,17}$ Pada penelitian ini ekspresi TGF beta 1 pada fibroblast yang dihitung dan diekspresikan pada sitoplasma dan membran sitoplasma.

Penghitungan ekspresi p63 secara kuantitatif pada sel-sel basal dan suprabasal epidermis serta pada sel-sel folikel rambut : 0 bila tidak ada ekspresi pada sel; +1 bila $<10 \%$ ekspresi sel positif; +2 bila 10-50\% ekspresi pada sel; +3 bila $>50 \%$ ekspresi pada sel. Intensitas diskor 0 bila tidak ada ekspresi pada sel; +1 bila ekspresi lemah; +2 bila ekspresi sedang; +3 bila ekspresi kuat. Dihitung pada 100 sel dari daerah hot spot. Kemudian dijumlah bila skor 0-1: negatif, 2: positif lemah, 3-4: positif sedang, 5-6: positif kuat. ${ }^{18}$

Variabel penelitian adalah: variabel bebas: placebo (Vaselin album), salep curcumin $0,1 \%$; dan variabel tergantung: ekspresi TGF- $\beta 1$, p63, waktu penutupan luka, tingkat inflamasi, dan penutupan dermal. Waktu penutupan luka merupakan waktu yang dibutuhkan untuk terbentuknya jaringan granulasi dengan baik (100\%).

Jaringan granulasi dianggap terbentuk dengan baik setelah parameter berikut ini terpenuhi: (a) lapisan yang kontinu dari jaringan granulasi sepanjang kedalaman luka, (b) lapisan jaringan granulasi memenuhi seluruh kedalaman luka. Bila polanya setempat-setempat, dianggap negatif. Inflamasi dilihat melalui tiga parameter yaitu: (a) sebukan leukosit yang padat di tempat gap luka (>200 sel dalam area tertentu, dengan pembesaran 200X), (b) banyak leukosit dalam pembuluh darah pada gap luka, dan (c) abses pada gap luka (Braiman-Wiksman et al., 2007). Luka dikategorikan sangat terinflamasi bila ada 2 parameter dalam gap luka. Penutupan dermal dilihat menggunakan pewarnaan H\&E (Braiman-Wiksman et al., 2007), dengan mengukur penutupan gap luka menggunakan ukuran mikrometer pada mikroskop binokuler (Olympus CX21) dengan pembesaran 40X. Luka dengan gap kurang dari $2 \mathrm{~mm}$ antara dua tepi dermal dianggap telah menutup. Penghitungan jarak celah ditentukan dengan cara mengkonfersi actual field of view 5 mikrometer dengan skala yang ada pada program microsoft paint 2007. Dengan perbesaran $100 \%$ pada microsoft paint 2007, satu kotak kecil = $1,875 \mathrm{~mm}$. Bila 5 mikrometer $=76$ kotak kecil, maka hasil konfersi adalah 142,5 $\mathrm{mm}$.

Rerata kadar ekspresi TGF- $\beta 1$, p63, dan faktor-faktor histopatologi dianalisa menggunakan uji non parametric marginal homogeneity dan kendall's tau-b.

\section{ANALISA DAN DISKUSI}

Penyembuhan luka bukanlah proses linier yang sederhana, di mana faktor-faktor pertumbuhan secara simultan mencetuskan pertumbuhan sel, tetapi merupakan suatu integrasi dari proses interaktif yang dinamik melibakan banyak sel, matrik ekstraseluler dan mediatormediator terlarut. ${ }^{19}$ Salah satu faktor pertumbuhan yang mempunyai peran utama dalam proses tersebut adalah 
TGF- $\beta 1$. TGF- $\beta 1$ dilepaskan oleh trombosit, neutrofil, limfosit, sel plasma, makrofag dan fibroblast. ${ }^{20}$ TGF beta1 merupakan regulator proses inflamasi pada luka. ${ }^{21,22}$ Peranan TGF- $\beta 1$ selama fase proliferasi adalah menstimulasi angiogenesis dan deposit kolagen dan mendorong migrasi keratinosit dan reepitelisasi. ${ }^{23,24}$ Dalam tahap lanjut proses penyembuhan, TGF- $\beta 1$ menginhibisi proliferasi berbagai sel dan tetap mengontrol komponenkomponen matrik ekstraseluler, bukan saja untuk mendorong produksinya tetapi juga untuk mengontrol substansisubstansi yang merusak matrik ekstraseluler. $^{25}$ Penurunan ekspresi TGF- $\beta 1$ pada tahap lanjut menginduksi keratinosit mengekspresikan integrin yang memfasilitasi komponen migrasi keratinosit yang mempercepat reepitelisasi. $^{26}$ Protein TGF- $\beta 1$ juga merupakan inhibitor endogen yang poten bagi proliferasi dan diferensiasi limfosit T dan B. ${ }^{27,28,29,30}$

Pada penelitian ini derajat inflamasi sampel luka kulit ketiga hewan coba Non $D M$ tanpa pemberian salep kurkumin (B) di hari pertama dan ke-3, masingmasing satu sampel terinflamasi berat dan dua sampel tidak terinflamasi, dan pada hari ke-12, ke-18, dan ke-30 tidak terinflamasi. Data ini dapat dilihat pada tabel 1. Bila dilihat level ekspresi TGF- $\beta 1$ hewan coba (B) pada tabel 2, penelitian ini mendukung teori di atas bahwa didapatkan hubungan antara level ekspresi TGF- $\beta 1$ dengan derajat inflamasi pada proses penyembuhan luka, dimana ekspresiTGF- $\beta 1$ cenderung meningkat di hari ketiga dan melemah pada hari ke-12, ke-18 dan ke-30. Pada uji korelasi kendall_tau, nilai koefisien korelasinya adalah 0,648 dengan nilai signifikansi 0,012 (signifikansi 0,05), sehingga dapat disimpulkan terdapat korelasi dan hubungan bermakna antara inflamasi dan level ekspresi TGF- $\beta 1$ pada penelitian ini. TGF- $\beta 1$ berperan dalam mencetuskan fase inflamasi dengan menarik neutrofil awalnya dan kemudian makrofag serta fibroblas masuk ke dalam lokasi luka yang terjadi pada hari pertama sampai ke-3. Pada fase proliferasi, maturasi dan remodeling ekspresi TGF- $\beta 1$ turun, karena inhibisi TGF- $\beta 3$ dalam jaringan granulasi yang diproduksi oleh leukosit, makrofag, fibroblas yang menunjukkan bukti stimulasi angiogenesis, proliferasi fibroblas, diferensiasi miofibroblas dan deposisi matrik ekstraseluler. ${ }^{31,32,33,34}$ Pembentukan jaringan granulasi sampel luka kulit (B) pada hari pertama sudah mulai terbentuk tetapi belum matang, hanya menunjukkan pembentukan pembuluh darah, baru di hari ke-3 dua sampel tertutup sempurna oleh jaringan granulasi yang matang dengan jumlah pembuluh darah yang sedikit dibandingkan sampel luka kulit yang belum tertutup sempurna oleh jaringan granulasi. Pada uji korelasi Kendall_ tau antara pembentukan jaringan granulasi dengan level ekspresi TGF- $\beta 1$, nilai koefisien korelasi 0,134 dengan signifikansi 0,602. Meskipun secara statistik tidak berkorelasi, tetapi hasil ini sesuai dengan teori diatas bahwa TGF- $\beta 1$ mempunyai hubungan dengan pembentukan jaringan granulasi, di mana TGF- $\beta 1$ merupakan faktor pertumbuhan bagi angiogenesis dan chemoattractan serta mitogenic factor bagi fibroblas pada fase inflamasi dan ekspresinya mulai menurun pada saat fase proliferasi. Penutupan dermal pada sampel luka kulit (B) belum terjadi pada hari ke-3, dermis menutup sempurna pada hari ke 12, di mana jaringan granulasi sudah terisi penuh oleh jaringan ikat fibrous. Fase proliferasi dimulai pada hari ke-4 diikuti dengan mulai terbentuknya jaringan granulasi 
sampai hari ke-7 dan maturasi jaringan granulasi dari hari ke-8 sampai ke-12. Jaringan granulasi telah digantikan sempurna oleh jaringan ikat kolagen pada hari ke-18 dan diikuti remodeling sampai hari ke-30. Pada penelitian ini TGF- $\beta 1$ masih diekspresikan pada level yang rendah dari hari ke-12 sampai hari ke-30 karena TGF- $\beta 1$ mempunyai peranan yang dinamis, di mana fase proliferasi TGF- $\beta 1$ berperan dalam produksi kolagen oleh fibroblas dan berperan mendorong produksi matrik ekstraseluler dan fase remodeling TGF- $\beta 1$ menghambat substansisubstansi yang merusak matrik ekstraseluler. Meskipun demikian pada uji Kendall_tau nilai koefisien korelasi $-0,138$ dengan signifikansi 0,590, sehingga didapatkan hubungan linear terbalik tetapi tidak bermakna.

Curcumin telah lama digunakan untuk mempercepat penyembuhan luka, dengan regenerasi epidermis lebih baik yaitu: pembentukan dan diferensiasinya; menunjukkan peningkatan jumlah neutrofil, makrofag, dan fibroblas; meningkatkan pembentukan jaringan granulasi sehingga lebih padat disertai banyak pembuluh darah; jumlah fibroblas lebih banyak dan kandungan kolagen lebih besar; serta mempercepat kontraksi luka oleh miofibroblas; menghambat kerusakan akibat hydrogen peroxidase pada keratinosit dan fibroblas. ${ }^{35,36,37,38,39}$ Pemberian curcumin secara topikal mencegah kerusakan jaringan oleh radikal bebas. ${ }^{40}$ Densitas pembuluh darah terpadat pada hari ke-4 setelah luka, peningkatan pembuluh darah ini bukannya tidak terkontrol, karena densitasnya menurun pada hari ke-7, sehingga dapat disimpulkan curcumin memperbaiki kemampuan jaringan secara fisiologis mempercepat penyembuhan, karena proliferasi pembuluh darah yang tidak terkontrol hanya mengakibatkan pembentukan jaringan granulasi eksuberan. TGF- $\beta$ merupakan chemoattractant bagi neutrofil dan fibroblas yang pada gilirannya mengontrol angiogenesis. ${ }^{41}$

Pada penelitian ini, derajat inflamasi pada sampel kulit ketiga hewan coba Non DM pemberian salep curcumin (A) pada hari pertama dan ke-3 masing-masing satu terinflamasi berat, dua sampel terinflamasi, dan pada hari ke-12, ke-18 dan ke-30, hanya satu sampel pada hari ke-18 menunjukkan inflamasi, selebihnya sampel luka kulit tidak terinflamasi. Data ini dapat dilihat pada tabel 1 . Ekspresi TGF- $\beta 1$ hewan coba (A) di tabel 2 , pada hari pertama semua sampel menunjukkan ekspresi kuat, pada hari ke-3 dua sampel ekspresinya kuat dan satu sampel ekspresinya sedang, hari ke-12 dua sampel ekspresinya kuat satu sampel ekspresinya sedang, hari ke-18 dua sampel ekspresinya kuat satu sampel negatif, hari ke-30 ketiga sampel ekspresinya sedang. Pembentukan jaringan granulasi pada sampel luka kulit hewan coba (A), pada hari pertama belum terbentuk jaringan granulasi matang, hanya menunjukkan pembuluh darah baru yang banyaknya berhubungan dengan tingkat inflamasinya. Baru pada hari ke-3 dan seterusnya, ketiga sampel kulit sudah tertutup sempurna oleh jaringan granulasi matang. Penutupan dermal belum terjadi pada hari ke-3, dermis menutup sempurna pada hari ke 12 , di mana jaringan granulasi sudah terisi penuh oleh jaringan ikat fibrous.

Pada penelitian ini, pemberian salep kurkumin meningkatkan derajat inflamasi dan level ekspresi TGF- $\beta 1$ pada luka insisi seluruh ketebalan kulit tikus wistar non diabetik (A) dibandingkan tanpa pemberian salep curcumin (B). Perbedaan ini konsisten, 
terjadi mulai hari pertama, ke-3, ke12, ke-18 dan hari ke-30. Pada uji marginal homogeneity derajat inflamasi sampel A terhadap sampel $B$ adalah $p=$ $0,166(p=0,05)$, level ekspresi TGF- $\beta 1$ sampel A terhadap B didapatkan nilai $p=0,03(p=0,05)$. Pada penelitian ini pembentukan jaringan granulasi yang menjadi indikator penutupan luka, menunjukkan pemberian curcumin pada ketiga sampel luka kulit (A) telah menutup dibandingkan sampel luka kulit (B) hanya dua sampel yang telah menutup pada hari ketiga, dengan uji marginal homogeneity didapatkan nilai $\mathrm{p}=0,317 \quad(\mathrm{p}=0,05)$. Pada penutupan dermis, satu sampel (A) telah menutup pada hari ke 3 dan sampel (B) baru menutup pada hari ke 12, dengan uji marginal homogeneity didapatkan nilai p 0,317 $(\mathrm{p}=0,05)$. Hasil penelitian ini sesuai dengan teori di atas bahwa curcumin meningkatkan derajat inflamasi dan level ekspresi TGF- $\beta 1$ yang cenderung mempercepat proses penyembuhan luka pada hewan coba non diabetes. Pada beberapa penelitian lain menyatakan, tidak adanya neutrofil dan monosit pada Smad3 null mice sehingga ekspresi TGF- $\beta 1$ juga rendah, terjadi reduksi pembentukan jaringan granulasi dan mempercepat proses penyembuhan dan bahwa curcumin menurunkan infiltrasi neutrofil ditunjukkan dengan penurunan indeks inflammatory infiltration secara kuantitatif, serta curcumin menunjukkan efek apoptosis pada neutrofil, sehingga hasil penelitian ini tidak sama dengan penelitian tersebut. ${ }^{42,43,44}$

Sel-sel epidermis

yang mengekspresikan p63 merupakan sel yang belum berdiferensiasi, berperan dalam proliferasi dan migrasi sel-sel epidermis dalam proses penyembuhan luka, menentukan diferensiasi epidermis, adesi sel dan pembentukan membran basal. ${ }^{45,46}$ Saat sel-sel punca basal mencapai suprabasal, ekspresi p63 sel-sel epidermis menurun, sehingga proliferasi berhenti, di mana transcient amplifying (TA) keratinocyte akan berdiferensiasi menjadi sel-sel epidermis di suprabasal dan tidak mempunyai potensi proliferasi ${ }^{47}$ Pada penelitian yang dilakukan oleh Waligora dan Noszczyk 2007, untuk mengetahui tingkat pembelahan sel-sel epidermis, peneliti tersebut menghitung tingkat ekspresi p63. ${ }^{48}$ Pada hari pertama dan ke dua, tidak ada perubahan ekspresi p63 epidermis di tepi luka tampak seperti kulit sehat. Pada hari ke 3 dan ke 4 migrasi dan stratifikasi sel-sel epidermis mulai terlihat dan ekspresi p63 mulai meningkat. Pada hari ke 5 banyaknya sel yang mengekspresikan p63 mencapai jumlah tertinggi. Setelah itu peningkatannya tidak signifikan. Pada hari ke 7 sampai ke 14 sel-sel epidermis telah menutup seluruh permukaan jaringan granulasi di mana sel-sel epidermis dominan mengekspresikan p63. Pada hari ke 20 ekspresi p63 turun setingkat dengan epidermis pada kulit sehat. Pada hari ke 28, ekspresinya sedikit meningkat.

Pada penelitian ini ekspresi p63 sampel B menunjukkan hari pertama ketiga sampel menunjukkan ekspresi sedang, hari ke-3 ekspresi satu sampel sedang, satu sampel lemah, satu sampel negatif, hari ke-12 ketiga sampel ekspresi sedang, hari ke 18 satu sampel ekspresi kuat dua sampel ekspresi sedang, hari ke-30 ketiga sampel ekspresi kuat. Pada sampel A ekspresi p63 adalah semua sampel dari hari pertama sampai ke-30 terekspresi kuat. Penelitian ini curcumin meningkatkan ekspresi p63 pada sel-sel punca epitel epidermis. Pembentukan jaringan granulasi menjadi pijakan untuk migrasi sel-sel epitel epidermis. TGF- $\beta$ memiliki 
peranan pembentukan miRNA dalam nukleus, di mana miRNA memfosforilasi p63 sehingga proliferasi melambat dan dilanjutkan diferensiasi. ${ }^{49}$

Keadaan hiperglikemia pada diabetes melitus, menyebabkan fase inflamasi lambat terjadi, meningkatkan produksi glycan end-product (AGEs) yang menginduksi produksi molekul inflamasi yaitu TNF alfa dan IL-1. ${ }^{50}$ Molekul tersebut menginduksi dan memperpanjang respon inflamasi, menyebabkan kondisi inflamasi kronik, meskipun inflamasi yang ringan, dan mengganggu sintesis kolagen. ${ }^{51,52}$ Penyembuhanlukaterjadisebagairespon seluler terhadap cedera melibatkan keratinosit, sel endotelial, makrofag dan trombosit. Luka kronik pada diabetes memiliki ciri khas penurunan ekspresi protein TGF- $\beta 1$ dan reseptor TGF- $\beta 1$ tipe II. ${ }^{53}$ TGF- $\beta 1$ penting dalam regulasi keseimbangan proliferasi, diferensiasi dan menonaktifkan sel-sel progenitor endotelial dari sumsum tulang.

Pada penelitian ini ketiga sampel C terinflamasi berat pada hari pertama dan satu sampel pada hari ke tiga dan satu sampel hari ke 18 terinflamasi, sisa sampel hari ke tiga, ke-12, ke-18, ke-30 tidak terinflamasi. Pembentukan jaringan granulasi ketiga sampel $\mathrm{C}$ pada hari pertama dan satu sampel hari ke-3 luka belum tertutup jaringan granulasi, sisa sampel hari ke-3, hari ke-12, hari ke18, hari ke-30 sudah tertutup jaringan granulasi. Penutupan dermis pada sampel $\mathrm{C}$, ke tiga sampel hari pertama dan hari ke-3 belum menutup, dermis menutup pada semua sampel pada hari ke-12, ke-18, ke-30. Bila dibandingkan dengan sampel $B$, tingkat inflamasi sampel C lebih tinggi, meskipun tidak bermakna secara statistik, dengan uji marginal homogeneity 0,225 ( $<<0,05)$. Pembentukan jaringan granulasi sampel $\mathrm{C}$ cenderung lebih lambat dibanding sampel B tetapi tidak bermakna secara statistik, dengan uji marginal homogeneity 0,564 ( $\mathrm{p}=$ 0,05). Pembentukan dermis sampel C dibanding sampel B tidak menunjukkan perbedaan. Level ekspresi TGF- $\beta 1$ sampel $C$ ketiga sampel hari pertama terekspresi kuat, satu sampel ekspresi sedang, dua sampel ekspresi negatif pada hari ke-3, ketiga sampel ekspresi negatif pada hari ke-12, ketiga sampel ekspresi kuat pada hari ke-18 dan ke-30. Pada uji marginal homogeneity TGF- $\beta 1$ sampel B dan sampel C didapatkan nilai $0,025(p=0,05)$, sehingga dapat disimpulkan ekspresi TGF- $\beta 1$ sampel $\mathrm{B}$ dan sampel $\mathrm{C}$ didapatkan perbedaan ekspresi yang bermakna, dimana ekspresi TGF- $\beta 1$ sampel C lebih kuat dibandingkan sampel B. Hasil penelitian ini, luka pada hewan coba diabetes menunjukkan respon inflamasi lebih lama bila dibandingkan non diabetes, dan menunjukkan sesuai dengan teori di atas, yaitu di mana semakin lama sel-sel inflamasi berada di lokasi luka menyebabkan cenderung lebih lambatnya pembentukan jaringan granulasi, meskipun demikian, pembentukan jaringan dermis pada hewan coba diabetes dan non diabetes tidak ada perbedaan. Pada penelitian ini level ekspresi TGF- $\beta 1$ hewan coba diabetes lebih kuat dibandingkan non diabetes, kondisi ini tidak sesuai dengan penelitian yang dikerjakan oleh Brunner et al., 2004, tetapi sependapat dengan hasil penelitian yang menyatakan bahwa level TGF- $\beta 1$ dalam serum darah sampel diabetes dan level TGF- $\beta 1$ di jaringan ulkus sampel diabetes lebih tinggi dibandingkan non diabetes. ${ }^{54,55,56}$ Tingginya level ekspresi TGF- $\beta 1$ pada hewan coba diabetik, cenderung menambah tingkat inflamasi, meskipun pada uji kendall's tau_b korelasi tersebut tidak signifikan $0,426(p<0,05)$, 
dan menyebabkan perlambatan proses penyembuhan, dapat dilihat dari kecenderugan melambatnya proses pembentukan jaringan granulasi dengan uji kendall's tau_b masingmasing TGF- $\beta 1=0,202$ dan inflamasi $=0,089$. Dapat disimpulkan tingginya level ekspresi TGF- $\beta 1$ dalam jaringan dan serum darah merupakan faktor penting dalam pembetukan luka kronik pada diabetes melitus. Penelitian ini sependapat dengan teori di atas dan sependapat dengan penelitian yang dikerjakan oleh Werner S dan Grose $\mathrm{R}$, tidak adanya neutrofil dan monosit pada Smad3 null mice, terjadi reduksi pembentukan jaringan inflamasi dan mempercepat proses penyembuhan. ${ }^{57}$

Pada telaah artikel oleh Gupta et al, tahun 2012 dan dipertegas dalam artikel oleh Chitragari et al, tahun 2013, menyebutkan curcumin mempercepat penyembuhan luka dengan menekan inflamasi, dengan mengatakan bahwa neutrofil dan makrofag pada ulkus kaki diabetes memproduksi radikal bebas dan protease yang meningkatkan inflamasi dan menurunkan penyembuhan luka. ${ }^{58,59}$ Curcumin memiliki aktifitas antibakterial terhadap berbagai gram negatif dan positif yaitu Staphylococcus aureus, Escherichia coli dan Pseudomonas yang merupakan organisme tersering ditemukan pada ulkus kaki diabetik. Pada hari ke-7 dan ke-11,luka diabetesyangdiolesicurcumin menunjukkan jaringan granulasi padat, peningkatan migrasi berbagai sel yaitu fibroblas dan miofibroblas, peningkatan jumlah pembuluh darah dan peningkatan kandungan kolagen. ${ }^{60}$ Pada penelitian yang dikerjakan oleh Dwivedi dan Chaudhary tahun 2012, luka pada tikus diabetik diterapi dengan Azadirachta indica dan Curcuma longa, tidak didapatkan debris nekrotik dan neutrofil pada hari ke-14.
Curcumin meningkatkan reepitelisasi, memperbaiki neovaskularisasi, dan meningkatkan migrasi berbagai sel pada penyembuhan luka kulit, disebabkan karena peningkatan level TGF- $\beta 1 .^{61,62}$

Pada hewan coba dibetik diterapi salep curcumin yaitu sampel $\mathrm{D}$, pada hari pertama satu sampel terinflamasi berat dua sampel terinflamasi, hari ke-3 ketiga sampel terinflamasi berat, pada hari ke-12 satu sampel terinflamasi berat dua sampel terinflamasi, pada hari ke-18 dan ke-30 semua sampel tidak terinflamasi. Pembentukan jaringan granulasi sampel $\mathrm{D}$, pada hari pertama ketiga sampel belum menutup, hari ke3, ke-12, ke-18, ke-30 semua sampel telah menutup. Pembentukan dermis pada sampel $\mathrm{D}$ hari ke-1, ke-3, ke-12 semua sampel belum mununjukkan penutupan dermis, hari ke-18 dan ke30 semua sampel telah menunjukkan penutupan dermis. Ekspresi TGF- $\beta 1$ sampel D hari pertama menunjukkan dua sampel terekspresi kuat satu sampel negatif, hari ke 3 dua sampel terekspresi kuat satu sampel terekspresi sedang, hari ke 12 dua sampel terekspresi kuat satu sampel terekspresi sedang, hari ke 18 dua sampel terkespresi kuat satu sampel negatif, hari ke 30 satu sampel terekspresi kuat dua sampel negatif.

Penelitian ini tidak sesuai dengan teori di atas dan menunjukkan inflamasi cenderung lebih berat dibandingkan sampel C tanpa terapi curcumin, meskipun tidak bermakna secara statistik uji marginal homogeneity 0,197 , pembentukan jaringan granulasi sampel D cenderung lebih lambat dibandingkan sampel $\mathrm{C}$ meskipun tidak bermakna secara statistik dengan uji marginal homogeneity 0,564 , sedang penutupan dermis sampel D lebih lama dibandingkan sampel C dengan uji marginal homogeneity 0,083 dan hal ini sejalan dengan ekspresi TGF- $\beta 1$ sampel 
D cenderung lebih tinggi dibandingkan sampel C meskipun tidak didapatkan perbedaan dengan uji marginal homogeneity 0,884.

Pada luka kulit kronik karena diabetes melitus sel-sel punca yang mengekspresikan p63 menurun. Bila dihubungkan dengan miRNA-203 dimana peningkatan regulasinya menurunkan ekspresi p63 sehingga proliferasi epitel epidermis menurun dilanjutkan diferensiasi menjadi transient amplifying (TA) keratinocyte. Pada hewan coba tikus diabetes diinduksi dengan streptozotocin, regulasi miR-203 meningkat 2 kali pada hari ke-3 dan menurun 0,8 kali pada hari ke 10 dibandingkan sebelum hari pertama. Bila dibandingkan dengan hewan coba tikus normal, sebelum hari pertama regulasinya menurun 0,7 , ada peningkatan miR-203 1,5 kali pada hari ke-3, dan menurun 0,6 kali pada hari ke-10. Karena itu pada hewan coba diabetes, penyembuhan luka akan terganggu karena fase proliferasi yang seharusnya diinisiasi pada 24 jam pertama setelah perlukaan, lambat.

Pada penelitian ini sampel $\mathrm{C}$ dua ekpresi p63 hari pertama satu sampel ekspresi kuat dua sampel ekspresi sedang, hari ke-3 satu sampel ekspresi kuat dua sampel ekspresi sedang, hari ke-12 dua sampel ekspresi kuat satu sampel ekspresi sedang, hari ke-18 dua sampel ekspresi kuat satu sampel ekspresi sedang, hari ke-30 ketiga sampel ekspresi kuat. Bila dibandingkan dengan hasil baik. ${ }^{42}$ Sampel B, ekspresi p63 pada hewan coba diabetes lebih kuat dengan uji marginal homogeneity 0,025 . Hasil penelitian ini tidak sesuai dengan teori di atas. Penelitian ini sesuai dengan penelitian yang dikerjakan oleh Usui et al., 2008. ${ }^{41}$ Penelitian tersebut menyatakan bahwa sel-sel epitel yang berada ditepi luka kronik dengan diabetes mellitus, proliferasinya meningkat. Protein p63 meningkatkan proliferasi sel-sel punca epidermis, yang dapat dikonfirmasi dengan pengecatan proliferating cell nuclear membrane (PCNA), yang akhirnya akan mempercepat penutupan luka meskipun protein TGF- $\beta 1$ pada awal proses penyembuhan menghambat proliferasi sel-sel punca epidermis, tetapi pada akhir proses penyembuhan meningkatkan proliferasi sel-sel punca. Pemberian curcumin meningkatkan reepitelisasi. Pada penelitian ini pemberian salep curcumin meningkatkan ekspresi p63 semua pada semua sediaan eksisi kulit tikus wistar baik non diabetik maupun diabetik, meskipun demikian waktu penyembuhan luka dan penutupan dermis pada kedua kelompok tidak menunjukkan perbedaan secara bermakna, hal ini dimungkinkan karena adanya infeksi pada luka kulit tikus wistar. Curcumin dapat memodulasi sel punca epitel epidermis, di mana terapi modulasi sel-sel punca sendiri maupun telah berdiferensiasi Transient Amplifying (TA) keratinocyte, mempercepat proses penyembuhan.

Tabel 1. Inflamasi dengan hari penyembuhan luka

\begin{tabular}{lccccc}
\hline Sangat terinflamasi & $1 / 1 / 3 / 1$ & $1 / 1 / 1 / 3$ & $0 / 0 / 0 / 1$ & $0 / 0 / 0 / 0$ & $0 / 0 / 0 / 0$ \\
Terinflamasi & $2 / 0 / 0 / 2$ & $2 / 0 / 0 / 0$ & $0 / 0 / 0 / 2$ & $1 / 0 / 0 / 0$ & $0 / 0 / 0 / 0$ \\
tidak terinflamasi & $0 / 2 / 0 / 0$ & $0 / 2 / 2 / 0$ & $3 / 3 / 3 / 0$ & $2 / 3 / 3 / 3$ & $3 / 3 / 3 / 3$ \\
$\begin{array}{l}\text { A\&B/ C\&D } \\
\text { p- tidak bisa dinilai } \\
\text { B\&C p= 0,625 }\end{array}$ & Hari ke 1 & Hari ke 3 & Hari ke 12 & Hari ke 18 & Hari ke 30 \\
\hline
\end{tabular}

Keterangan tabel 1 dan 2: A/B/C/D. A: Non DM kurkumin (+), B: Non DM kurkumin (-), C: DM kurkumin (-), D: DM kurkumin (+) 
Tabel 2. Ekspresi TGF - $\beta 1$ dengan hari penyembuhan luka

\begin{tabular}{lccccc}
\hline Ekspresi kuat & $3 / 1 / 3 / 2$ & $2 / 1 / 0 / 2$ & $2 / 0 / 0 / 2$ & $2 / 0 / 3 / 2$ & $0 / 0 / 3 / 1$ \\
Ekspresi sedang & $0 / 0 / 0 / 0$ & $1 / 0 / 1 / 1$ & $1 / 0 / 0 / 1$ & $0 / / 0 / 0 / 0$ & $3 / 0 / 0 / 0$ \\
Ekspresi lemah & $0 / 0 / 0 / 0$ & $0 / 2 / 0 / 0$ & $0 / 2 / 0 / 0$ & $0 / 3 / 0 / 0$ & $0 / 2 / 0 / 0$ \\
Negatif & $0 / 2 / 0 / 1$ & $0 / 0 / 2 / 0$ & $0 / 1 / 3 / 0$ & $1 / 0 / 0 / 1$ & $0 / 1 / 0 / 2$ \\
A\&B p=0,136 & Hari 1 & Hari 3 & Hari 12 & Hari 18 & Hari 30 \\
C\&D p $=0,342$ & & & & & \\
\hline
\end{tabular}

Keterangan tabel 1 dan 2: A/B/C/D. A: Non DM kurkumin (+), B: Non DM kurkumin (-), C: DM kurkumin (-), D: DM kurkumin (+)

Tabel 3. Jaringan granulasi dengan hari penyembuhan

\begin{tabular}{lccccc}
\hline Luka sudah menutup & $0 / 0 / 0 / 0$ & $0 / 2 / 2 / 3$ & $3 / 3 / 3 / 3$ & $3 / 3 / 3 / 3$ & $3 / 3 / 3 / 3$ \\
Luka belum menutup & $3 / 3 / 3 / 3$ & $3 / 1 / 1 / 0 /$ & $0 / 0 / 0 / 0$ & $0 / 0 / 0 / 0$ & $0 / 0 / 0 / 0$ \\
A\&B p=0,500 & Hari 1 & Hari 3 & Hari 12 & Hari 18 & Hari 30 \\
C\&D $p=0,500$ & & & & & \\
B\&C $p=1,000$ & & & & & \\
\hline
\end{tabular}

Tabel 4. Penutupan dermis dengan hari penyembuhan luka

\begin{tabular}{lccccc}
\hline Sudah menutup & $0 / 0 / 0 / 0$ & $0 / 0 / 0 / 0$ & $3 / 3 / 3 / 0$ & $3 / 3 / 3 / 3$ & $3 / 3 / 3 / 3$ \\
Belum menutup & $3 / 3 / 3 / 3$ & $3 / 3 / 3 / 3$ & $0 / 0 / 0 / 3$ & $0 / 0 / 0 / 0$ & $0 / 0 / 0 / 0$ \\
A\&B p $=1,000$ & Hari 1 & Hari 3 & Hari 12 & Hari 18 & Hari 30 \\
C\&D $p=0,250$ & & & & & \\
B\&C $p=1,000$ & & & & & \\
\hline
\end{tabular}

Keterangan tabel 3 dan 4. A/B/C/D. A: Non DM kurkumin (+), B: Non DM kurkumin (-), C: DM kurkumin $(-)$, D: DM kurkumin (+)

Tabel 5. Ekspresi p63 dengan hari penyembuhan luka

\begin{tabular}{llllll}
\hline Ekspresi sedang & $0 / 3 / 2 / 0$ & $0 / 1 / 2 / 0$ & $0 / 3 / 1 / 0$ & $0 / 2 / 1 / 0$ & $0 / 0 / 0 / 0$ \\
Ekpresi kuat & $3 / 0 / 1 / 3$ & $3 / 0 / 1 / 3$ & $3 / 0 / 2 / 3$ & $3 / 1 / 2 / 3$ & $3 / 3 / 3 / 3 /$ \\
Ekspresi lemah & $0 / 0 / 0 / 0$ & $0 / 1 / 0 / 0$ & $0 / 0 / 0 / 0$ & $0 / 0 / 0 / 0$ & $0 / 0 / 0 / 0$ \\
Negatif & $0 / 0 / 0 / 0$ & $0 / 1 / 0 / 0$ & $0 / 0 / 0 / 0$ & $0 / 0 / 0 / 0$ & $0 / 0 / 0 / 0$ \\
A\&B/C\&D & & & & & \\
p-tidak bisa dinilai & & & & & Hari 18 \\
A\&D p=0,870 & Hari 1 & Hari 3 & Hari 12 & Hari 30 \\
\hline
\end{tabular}

Keterangan tabel 3 dan 4. A/B/C/D. A: Non DM kurkumin (+), B: Non DM kurkumin (-), C: DM kurkumin $(-)$, D: DM kurkumin (+) 


\section{KESIMPULAN DAN SARAN}

Pada penelitian ini, ekspresi TGF- $\beta 1$ berhubungan dengan proses penyembuhan luka normal. Curcumin dalam ekstrak etanol Curcuma longa terpurifikasi etil asetat meningkatkan ekspresi TGB- $\beta 1$ dan p63 dan cenderung mempercepat proses penyembuhan luka normal. Ekspresi TGF- $\beta 1$ pada luka non diabetik lebih rendah dibandingkan diabetik, dengan disertai perburukan proses penyembuhan luka dengan menunjukkan peningkatan tingkat inflamasi pada luka diabetik. Pada penelitian ini, pemberian curcumin pada luka diabetik berhubungan dengan ekspresi p63, tidak berhubungan dengan ekspresi TGF- $\beta 1$.

Luka kronik menjadi dapat menjadi salah satu lesi prakanker, dengan meningkatnya ekspresi TGF- $\beta 1$ oleh curcumin pada luka kronik akan menyebabkan berhentinya pertumbuhan sel-sel epitel epidermis secara berlebihan dan proses ini juga dapat terjadi pada kanker stadium awal. Terapi modulasi sel-sel punca maupun yang telah berdiferensiasi merupakan cara untuk mempercepat proses penyembuhan dengan hasil yang baik, sehingga Curcuma longa menjadi salah satu herbal yang mampu memodulasi penyembuhan luka.

Peneliti menyarankan penelitian dengan jumlah sampel yang lebih besar dan tertuju pada satu kondisi klinis, sehingga khasiat curcumin pada proses penyembuhan luka dapat benar-benar diketahui.

Kelemahan penelitian ini adalah didapatkan beberapa sediaan yang tidak dapat dinilai baik potongan yang rusak saat proses pengecatan imunohistokimia, pengecatan imunohistokimia dengan background staining, analisa histopatologi dan imunohistokimia dikerjakan satu orang.

\section{DAFTAR PUSTAKA}

1. Yasa IWP, Suastika K, Djelantik AAGS, Astawa IYM. Hubungan positif antara ulkus kaki diabetic dengan presentase sel bermarka CD4+ pembawa malondialdehid. Journal of Internal Medicine 2009 Januari; 10(1): 1-21

2. Clayton W, Elasy TA, 2009. A Review of the Pathophysiology, Classification, and Treatment of Foot Ulcers in Diabetic Patients. Clinical Diabetes, volume 27, number 2: 528.

3. Demidova-Rice TN, Durham JT, Herman IM, 2012.Wound Healing Angiogenesis: Inovation and Challenges in Acute and Chronic Wound Healing. Advances In Wound Care, volume 1, number 1 , doi: 10.1089/wound.2011.0308.

4. Jude EB, Blakytny R, Bulmer J, Boulton AJ, Ferguson MW, 2002. Transforming growth factor-beta 1, 2, 3 and receptor type I and II in diabetic foot ulcers. -Diabet. Med. -; 19(6); 440-7.

5. Nair RP, Krishnan LK, 2013. Identification of $\mathrm{p} 63^{+}$keratinocyte progenitor cells in circulation and their matrix-directed differentiation to epithelial cells. Stem Cell Research \& Therapy, 4: 38.

6. Bascom CC, Wolfshohl JR, Coffey Jr RJ, Madisen L, Webb NR, Purchio AR, Derynck R, Moses HL; 1989. Complex regulation of transforming growth factor beta1, beta2, beta3 mRNA expression in mouse fibroblas and keratinocyte by transforming factor beta1 and beta2. Molecular and Cellular Biology, volume 9, no12: 5508-15.

7. Barui A, Banerjee P, Das RK, Basu SK, Dhara S, Chatterjee J, 2011. Immunohistochemical Evaluation of p63, E-Chaderin, Collagen I 
and III Expression in Lower Limb Wound Healing under Honey. Evidence-Based Complementary and Alternative Medicine, volume 2011, Article ID 239864, 8 pages.

8. Kulac M, Aktas C, Tulubas F, Uygur R, Kanter M, Erboga M, Ceber M, Topcu B, Ozen OA, 2013. The effects of topical tratment with curcumin in burn wound healing in rats. Journal of Molecular Histology, 44 (1): 8390.

9. Braiman-Wiksman L, Solomonik I, Spira R, Tennenbaum T; 2007. Novel insight into wound healing sequence of events. Toxicologic Pathology, 35: 767-79.

10. Lima MHM, Caricilli AM, de Abreu LL, Araujo EP, Pelegrinelli FF, Thirone ACP, Tsukumo DM, Pessoa AFM, dos Santos FM, de Moraes MA, Carvalheira JBC, Velloso LA, Saad MJA, 2012. Topical insulin accelerates wound healing in diabetes by enhancing the AKT and ERK pathway: Adoouble-blind placebe-controlled clinical trial. PLoS ONE 7(5): e36974.

11. Mani H, Sidhu GS, Kumari R, Gaddipati JP, Seth P, Maheshwari RK, 2002. Curcumin differentially regulates TGF- $\beta 1$, its receptors and nitric oxide synthase during impaired wound healing. BioFactors $16 ; 29-43$.

12. Culhaci N, Sagol O, Karademir S, Astarcioglu H, Astarcioglu I, Soyturk M et al 2005. Expression of transforming growth factor beta- 1 and $\mathrm{p} 27^{\mathrm{Klp}} \mathrm{I}$ in pancreatic adenocarcinoma: relation with cell-cycle associated proteins and clinicopathologic characteristics. Boston Medical Center Cancer, 5:98.

13. Brandes ME, Mai UE, Ohura K, Wahi SM, 1991. Type I transforming factor-beta receptors on neutrophil mediate chemotaxis to transforming growth factor beta; Journal of Immunology, 147(5): 1600-6.

14. Epivatianos A, Andreadis D, Iordanidis S, 2013. Myofibroblasts and Transforming Growth FactorBeta 1 in Reactive Gingival Overgrowths. Journal of Oral \& Maxillofacial Research, vol.4, no 1, e3.

15. Das RK, Venkatraghavan V, Sheet D, Chakraborty C, Ray AK, Chatterjee J, 2010. Evaluation of p63 Expression in Oral Submukus Fibrosis. Proceedings of 2010 International Conference on Systems in Medicine and Biology.

16. Crowe $M$, Doetschman $T$, Greenhalgh DG, 2000. Delayed Wound Healing in Immunodeficient TGF- $\beta 1$ Knockout Mice. The Journal of Investigative Dermatology. Vol. 115, No. 1.

17. Werner S, Grose R, 2003. Regulation of Wound Healing by Growth Factors and Cytokines. Physiol Rev, 83: 835-870.

18. Valluru M, Staton CA, Reed MWR, Brown NJ, 2011. Transforming growth factor- $\beta$ and endoglin signaling orchestrate wound healing. Frontiers in physiology, volume 2, article 89.

19. Guo S, DiPietro LA, 2010. Factors Affecting Wound Healing. Critical Review in Oral Biology Medicine. Journal of Dental Research, 89 (3) 219-229.

20. Brunner G, Blakytny R, 2004. Extracellular regulation of TGF- $\beta$ activity in wound repair: growth factor latency as a sensor mechanism for injury. Journal of Thrombosis and Haemostasis, 92: 253-61.

21. Shah M, Foreman DM, Ferguson MWJ, 1995. Neutralisation of 
TGF- $\beta 1$ and TGF- $\beta 2$ or addition of TGF- $\beta 3$ to cutaneous rat wounds reduces scarring. Journal of Cell Science 108: 985-1002.

22. Ashcroft GS, Yang $X$, Glick AB, Weinstein M, Letterio JJ, Mizel DE, Anzano M, Greenwell-Wild T, Wahl SM, Deng C, Roberts AB, 1999. Mice lacking Smad3 show accelerated wound healing and an impaired local inflammatory response. Nature Cell Biology, volume 1: 260-66.

23. Yang L, Chan T, Demare J, Iwashina T, Ghahary A, Scott PG, Tredget EE, 2001. Healing of Burn Wounds in Transgenic Mice Overexpressing Transforming Grwoth Factor- $\beta 1$ in the Epidermis. American Journal of Pathology, Volume 159, No. 6: 2147-57.

24. Sidhu GS, Mani H, Gaddipati JP, Singh AK, Seth P, Banaudha KK, Patnaik GK, Maheshwari RK, 1999. Curcumin enhances wound healing in streptozotocin induced diabetic rats and genetically diabetic mice. Wound Repair and Regeneration, volume 7 , Issue 5 ; 362-74.

25. Singer AJ, McClain SA, Romanov A, Rooney J, Zimmerman T, 2007. Curcumin Reduces Burn Progression in Rats. Academic Emergency Medicine, Volume 14, No.12: 1125-29.

26. Chitragari G, Sumpio BJ, Sumpio $\mathrm{BE}, 2013$. Indian Spices for the Managemen of Diabetic Foot Complications. Review Article. Angiology: Open Access, Volume 1, Issue 2, 1000114.

27. Gopinath D, Ahmed MR, Gomathi K, Chitra K, Sehgal PK, Jayakumar $\mathrm{R}$, 2004. Dermal pwund healing processes with curcumin incorporated collagen films. Biomaterials, 2 (10): 1911-7.
28. Chereddy KK, Coco R, Memvanga PB, Ucakar B, des Rieux A, Vandermeulen G, Preat V, 2013. Combined effect of PLGA and curcumin on wound healing activity. Journal of Controlled Release, 171: 208-15.

29. Jacob A, Wu R, Zhou M, Wang $P, 2007$. Mechanism of the Antiinflammatory Effect of Curcumin: PPAR $-\gamma$ Activation. Review Article. Hindawi Publishing Corporation, Volume 2007, Article ID 89369.

30. Waligora J, Noszczyk B, 2007. Proliferation and ability for epidermal autogeneration in patiens with chronic lower leg venous ulcerations. Polski Przeglad Chirurgiczny, 79, 2: 113: 19.

31. Mills SJ, Cowin AJ, 2012. MicroRNAs and their roles in wound repair and regeneration. Wound Practice Research, Volume 21 Number 1.

32. Tsourdi E, Barthel A, Rietzsch $\mathrm{H}$, Reichel A, Bornstein SR, 2013.Current Aspects in the Pathophysiology and Treatment of Chronic Wounds in Diabetes Melitus. Biomed Research International, Volume 2013, Article ID 285641.

33. Tellechea A, Leal E, Veves A, Carvalho E, 2010. Inflammatory and Angiogenic Abnormalities in Diabetic Wound Healing: Role of Neuropeptides and therapeutic Perspectives. The Open Circulation and Vascular Journal, 3: 43-55.

34. Werner S, Grose R, 2003 Regulation of Wound Healing by Growth Factors and Cytokines. Physiological Review; 83; 3: 83-70.

35. Bhatwadekar AD, Guerin EP, Jarajapu YPR, Caballero S, Sheridan C, Kent D, Kennedy L, Lansang MC, Ruscetti FW, Pepine CJ, Higgins PJ, Bartelmez SH, Grant MB, 2010. Transient Inhibition of Transforming 
Growth Factor- $\beta 1$ in Human

Diabetic $\mathrm{CD} 4^{+}$Cells Enhances

Vascular Reparative Functions.

Diabetes, Volume 9: 2010-19.

36. Brem H, Tomic-Canis M, 2007. Cellular and molecular basis of wound healing in diabetes. The Journal of Clinical Investigation, Volume 117, Number: 1219-22.

37. Loffler M, Schmohl M, SchneiderhanMarra N, Beckert S. Wound Fluid Diagnostics in Diabetic Food ulcers. Dalam Dinh T, editor, 2011. Global Perspective on Diabetic Foot Ulcerations. InTech, Croatia.

38. Gupta SC, Patchva S, Koh W, Aggarwal BB, 2012. Discovery of Curcumin, a Component of the Golden Spice, and Its Miraculous Biological Activities. Clinical and Experimental Pharmacology and Physiology, 39 (3): 283-99.

39. Dwivedi VK, Chaudhary M, 2012.

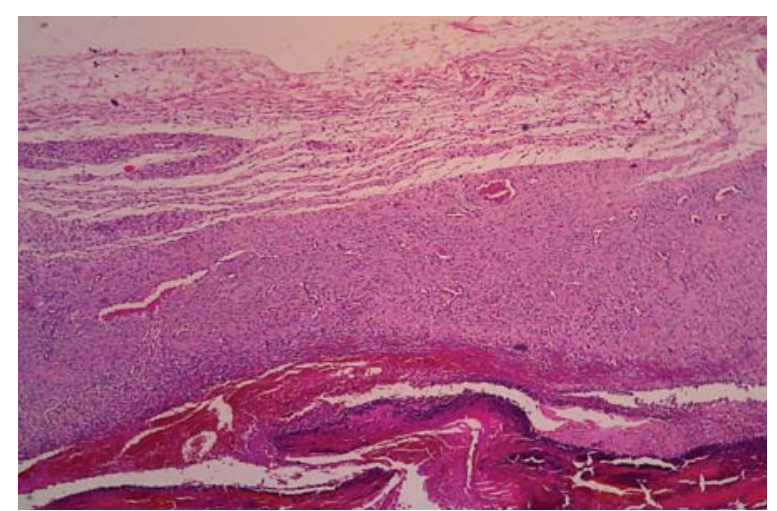

1
Comparative wound healing efficacy of ampucare and becaplermin in diabetic rat. African Journal of Pharmacy dan Pharmacology, Volume 6 (12): 883-92.

40. Zhang DW, Fu M, Gao SH, Liu JL, 2013.Curcumin and Diabetes: Asystemic Review. Review Article. Evidence-Based Complementary and Alternative Medicine, Volume 2013, Article ID 636053.

41. Usui ML, Mansbridge JN, Carter WG, Fujita M, Olerud JE, 2008. Keratinocyte Migration, Proliferation, and Differentiation in Chronic Ulcers From Patients With Diabetes and Normal Wounds. Joournal \& Histochemistry, Volume 6 (7): 687-96.

42. Senoo M, 2013. Epidermal Stem Cells in Homeostasis and Wound Repair of the Skin. Advances in Wound Care, Volume 2, Nuber 6:

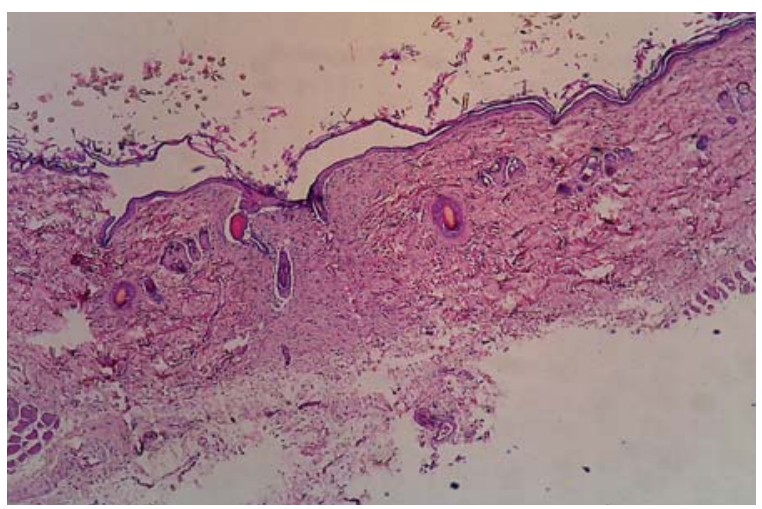

2

Gambar 1. Jaringan granulasi mengisi gap luka, dan jumlah leukosit pmn di dalam jaringan granulasi lebih dari 200 sel bila dilihat dengan perbesaran 400 kali pada beberapa daerah hot spot. Daerah di dalam lingkaran menunjukkan eksudat. Gambar 2. Jaringan ikat fibrous telah mengisi seluruh daerah dermis. 


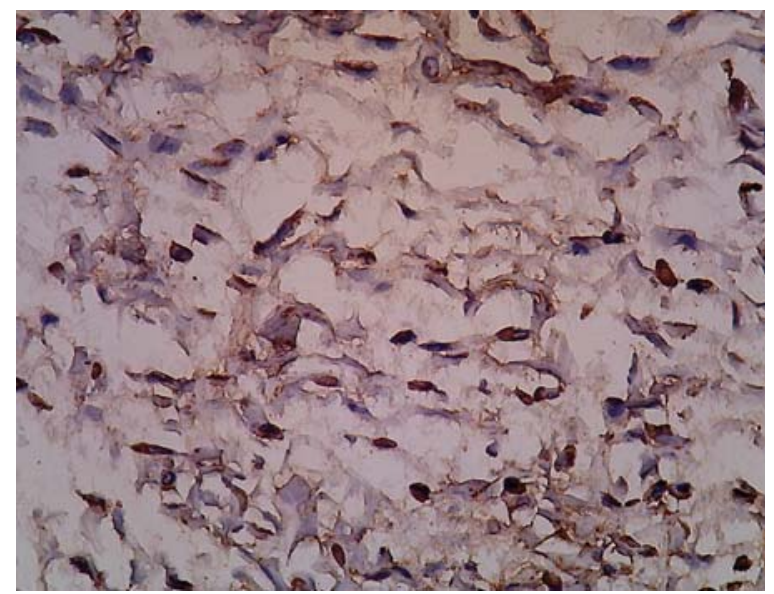

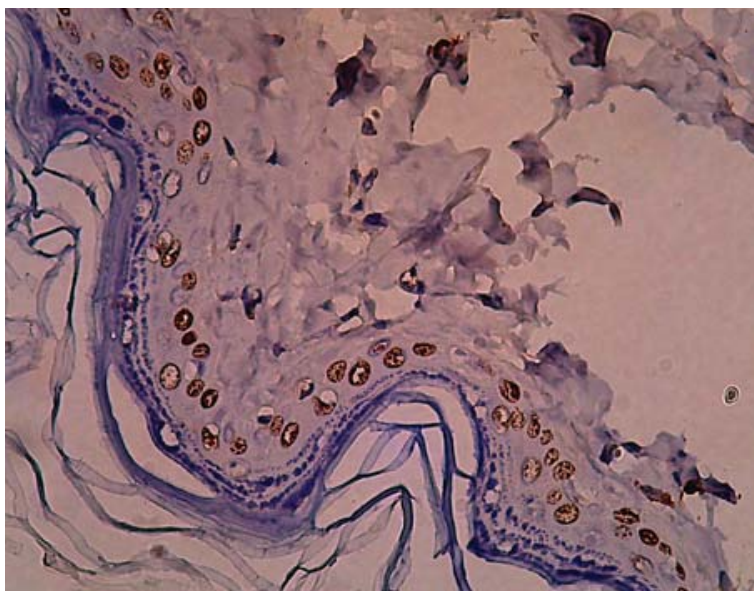

Gambar 3. TGF- $\beta 1$ terekspresi pada sitoplasma fibroblast. Gambar 4. p63 terekspresi pada inti sel epitel epidermis. 